\title{
KEMERDEKAAN MENYAMPAIKAN PENDAPAT DI MUKA UMUM SEBAGAI MAKAR MENURUT KUHP
}

\author{
Fanny Fauzie
}

Univertsitas Andalas, fannyfaurie@gmail.com

\author{
Diterima: 4 September $2019 \quad$ Direvisi:15 Desember $2019 \quad$ Diterbitkan: 25 Desember 2019
}

\begin{abstract}
KUHP (Penal Code Of Indonesia) is a positive Indonesian criminal law regulation which in its history, came from the Wetboek van Strafrecht voor Nederlandsch Indie (WvSNI) which contains about the crimes against the security of the state as regulated in the sub first chapter of the KUHP itself. Van Toelichting's Memorie mentioned that treason is a translation of the Aanslag, which, if paired into English, can be interpreted as an attempt or attack. According to 87 th Article of the Criminal Code, if treason has commenced according to Article 53th of the Criminal Code (Trial), on the other hand, there is a The1945 Constitution which is a Grundnorm that guarantees the freedom to express opinions that publicly as in 28th E Article, 3rd paragraph. And also, regulated explicitly in 39th Law Number, the year 1999 about expressing opinions in public, so if referring to treason as an experiment as Article 53 of the Criminal Code, it would prevent anyone from criticizing by communicating and issuing opinions. If the notice was addressed to the government by saying the current government is not good and must be replaced, the presence of the 87th Article about the Criminal Code certainly experiments intention. And the crimes against state security are also referred to as political offenses, to determine the suspects in this political offense, an in-depth study must be carried out, so this is the reason why the writing is carried out. The typology of the research used is the normative juridical (doctrinal) library method. So in this study, we can see whether it is appropriate if the criminal offense of this treason can be applied as the 87th. Article about Criminal Code without interpreting the betrayal as an aanslag or attempt or an attack. connected to the existence of Guarantees in Delivering Opinions.
\end{abstract}

Keywords: The Freedom in Delivering Opinions, Treason, Aanslag.

\begin{abstract}
Abstrak
KUHP yang merupakan peraturan bukum pidana positif Indonesia yang dalam sejarahnya berasal dari Wetboek van Strafrecht voor Nederlandsch Indie (WvSNI) dimana didalamnya termuat kejahatan terbadap keamanan negara yang diatur dalam Sub BAB I buku Kedua KUHP. Didalam memorie van toelichting disebutkan makar merupakan terjemahan dari Aanslag yang jika dipadankan kedalam bahasa Ingris dapat diartikan Atempt atau sebagi Serangan. Menurut pasal 87 KUHP adalah apabila telah dimulainya perbuatan makar sebagaimana menurut pasal 53 KUHP (Percobaan), disisi lain terdapat UUD 1945 yang merupakan Grundnorm yang menjamin kebebasan menyampaiakan pendapat dimuka umum termaktub dalam Pasal 28E ayat 3, dan juga diatur secara spesifik dalam UU Nomor 39 Tabun 1999 tentang menyampaikan pendapat dimuka umum, sehingga jika merujuk makar sebagai suatu percobaan sebagaimana Pasal 53 KUHP, akan menghambat setiap orang untuk mengkritisi dengan menyatakan dan mengeluarkan pendapat, jika pendapat tersebut ditujukan kepada pemerintah dengan mengatakan pemerintah saat ini tidak baik dan harus diganti, dengan kehadiran Pasal 87 KUHP tentu menjadikan percobaan dalam niat. Dan kejahatan terbadap keamanan negara juga disebut sebagai delik politik, tentu untuk menetapkan tersangka dalam delik politik ini harus dilakukan kajian mendalam, maka untuk itu penulisan ini dilakukan pendekatan Tipologi penelitian yang digunakan adalah metode kepustakaan yang bersifat yuridis normatif (doktriner). Sehingga kajian ini dapat melihat apakah tepat jika tindak pidana makar ini dapat diterapkan sebagaimana Pasal 87 KUHP tanpa mengartikan makar tersebut sebagai aanslag atau Atempt tau serangan dibubungkan dengan adanya Jaminan dalam Kebebasan Menyampaikan Pendapat.
\end{abstract}

Kata Kunci: Kemerdekaan Menyampaikan Pendapat, Makar, Aanslag. 


\section{PENDAHULUAN}

Indonesia adalah negara hukum (rechstaat) sebagaimana ketentuan pasal 1 ayat (3) UUD 1945 amandemen ketiga. Pada dasarnya, konsep negara hukum merupakan bagian tak terpisahkan dari doktrin rule of law dari A.V. Dicey yang terdiri atas 3 (tiga) unsur yaitu Supremacy Of Law (Supremasi Hukum), Equality Before The Law (Persamaan di hadapan hukum) ${ }^{1}$, dan Constitution Based On Human Rights (Konstitusi yang berdasarkan Hak Asasi Manusia). Maka Indonesia mengatur perlindungan Hak Asasi Manusia (HAM) tersebut dalam konstitusinya. Perlindungan hak asasi manusia diberikan kepada semua orang, begitu pula terhadap kebebasan dalam menyatakan pendapat dimuka umum, Konstitusi Repubik Indonesia mengaturnya kedalam Pasal 28E ayat 3 UUD 45 yang ditegaskan kedalam UU Nomor 39 Tahun 1999 dimana dalam Pasal 25 nya dinyatakan "Setiap orang berbak untuk menyampaikan pendapat di muka umum, termasuk bak untuk mogok sesuai dengan ketentuan peraturan perundang-undangan". Untuk menyampaikan pendapat dimuka umum adalah suatu hak asasi manusia.

Negara menetapkan aturan-aturan serta kebijakan-kebijakan untuk mengatur masyarakat. Kekuasaan yang dijalankan oleh pemerintah/penguasa dapat diartikan sebagai tindakan negara. Termasuk dalam pemberlakuan Kitap Undang Undang Hukum Pidana yang biasa disebut KUHP yang ditegaskan keberlakuannya berdasarkan Undang-Undang Nomor 73 tahun 1958 Tentang Menyatakan Berlakunya UndangUndang Nomor 1 tahun 1946 Republik Indonesia Tentang Peraturan Hukum Pidana Untuk Seluruh Wilayah Republik Indonesia dan Mengubah Kitab Undang-Undang Hukum Pidana.

${ }^{1}$ Lihat Jimly Asshiddiqie dalam Muhammad Tahir Azhary, et al, Beberapa Aspek Hukum Tata Negara, Hukum Pidana, dan Hukum Islam, Jakarta: Kencana, 2012). 27
Dalam KUHP yang mengatur tentang kejahatan dan pelanggaran tentu dengan tujuan terciptanya kondisi, aman, tentram dan damai dalam negara sehingga pemerintah atau penguasa dapat menjalankan fungsi negara dengan baik sehingga mencapai pembangunan sesuai dengan yang dicitakan.

Dalam menegakkan aturan dan kebijakan untuk tercapai kondisi aman dan tenteram sebagaimana diatas, maka negara membentuk lembaga kepolisian, dimana karakteristik profesi kepolisian, harus diketahui bukan hanya penegak hukum, melainkan juga memiliki tugas dan kewenangan lain sebagai penegak keamanan dan ketertipan masyarakat dan perlindungan masyarakat ${ }^{2}$.

Kejahatan tidak saja terjadi antara elemen-elemen manusia sebagai warga negara, adakalanya kejahatan itu ditujukan kepada penguasa atau pemerintah yang memiliki legitimasi kekuasaan yang sah, terhadap hal yang demikian KUHP juga mengatur dalam Bab I Buku Kedua mengenai kejahatan terhadap keamanan negara dengan disertakannya Pasal-Pasal mengenai kejahatan terhadap negara, yakni Pasal 87, Pasal 104, Pasal 106, Pasal 107, Pasal 139a, Pasal 139b dan Pasal 140.

Kemudian pada tanggal 19 Mei 1999 pemerintah kembali mengundangkan UndangUndang Republik Indonesia Nomor 27 tahun 1999 Tentang Perubahan Kitab UndangUndang Hukum Pidana Yang Berkaitan dengan Kejahatan Keamanan Negara, alasan diundangkannya Undang-Undang tersebut adalah $^{3}$; bahwa KUHP belum memiliki landasan yang kuat dalam usaha mempertahankan negara Republik Indonesia yang berlandaskan Pancasila, dengan demikian

2 Achmad Ali, Menguak Teori Hukum (Legal Theory) dan Teori Peradilan (Judicialprudence) Termasuk Integritasi Undang-Undang (Legisprudence), (Jakarta: Kencana, 2009). 509

${ }^{3}$ Konsideran Undang-Undang Nomor 27 Tahun 1999 huruf b 
ditambahkan 6 (enam) pasal baru dalam KUHP, yang dijadikan Pasal 107a, 107b, 107c, 107d, 107e, 107f.

Pada Kitab Undang-Undang Hukum Pidana Pasal 107 dinyatakan bahwa, Makar (aanslag) adalah perbuatan yang ditujukan untuk menggulingkan pemerintahan (omwenteling), dimana dalam perbendaharaan hukum pidana telah lazim diterjemahkan dengan kata Makar. ${ }^{4}$ Suatu perbuatan dikatakan Makar, menurut pasal 87 KUHP adalah apabila telah dimulainya perbuatan makar sebagaimana menurut pasal 53 (Percobaan). Makar (aanslag) dilakukan dengan perbuatan kekerasan. Secara yuridis, apabila seseorang melakukan perbuatan persiapan (voorbereidings-hendeling), ia belum dapat dihukum. Perbuatan Makar sebagaimana dimaksud pasal 107 KUHP dan 110 KUHP adalah ketika sudah mulai melakukan perbuatan pelaksanaan (uitvoeringshandeling).

Adapun kekuasaan negara dibatasi oleh Konstitusi sebagai ketentuan dasar negara yang mengatur kewajiban pokok negara kepada rakyat, bahwa kekuasaan di suatu negara tidak boleh berjalan sewenang-wenang. Untuk itulah dibuat undang-undang yang tidak hanya mengatur masyarakat tapi juga mengatur kekuasaan agar menjadikan negara ini negara hukum yang berkeadilan Menjadikan hukum sebagai panglima bukan kekuasaan sebagai panglima dengan demikian rakyat dapat ikut serta dalam memajukan negara dengan cara memberikan, masukan dan kritikan kepada pemerintah/ penguasa, baik dengan cara mengirimkan wakil melalui lembaga legislatif maupun berorasi mengeluarkan pendapat, membuat aksi agar dapat perhatian yang serius dari pemerintah, kebebasan mengeluarkan mengemukakan pendapat adalah HAM setiap manusia tanpa terkecuali yang dijamin oleh konstitusi negara Indonesia sebagaimana Pasal

\footnotetext{
${ }^{4}$ Adami Chazawi, Kejahatan Terhadap Keamanan dan Keselamatan Negara, (Jakarta: Rajawali Pers, 2002). 7
}

28E Undang-Undang Dasar 1945 karena hal tersebut merupakan hak asasi dari masyarakat atau manusia. Dalam hal hak asasi untuk mengeluarkan pendapat, sebagai negara hukum yang demokratis, Negara Kesatuan Republik Indonesia menjabarkan dan menuangkannya kedalam Undang-Undang Nomor 9 tahun 1998 tentang Kemerdekaan Menyampaikan Pendapat di Muka Umum.

Pada ketentuan Pasal 9 (1) "Bentuk. penyampaian pendapat di muka umum dapat dilaksanakan dengan: a. unjuk rasa atau demonstrasi; b. pawai; c. rapat umum; dan atau $d$. mimbar bebas".

Tindak pidana makar identik dengan usaha untuk meruntuhkan atau menggulingkan kekuasaan pemerintah yang mempunyai legitimasi yang sah, sehingga tindak pidana makar syarat dengan tendensi dari pemerintahan yang berkuasa, tentu dengan syarat demikian menjadikan kejahatan makar menjadi kejahatan yang luar biasa yang rasanya tidak bisa disejajarkan dengan kejahatan lain dalam KUHP, bisa saja tindak pidana makar dilakukan oleh lawan-lawan politik dari pemerintah yang berkuasa, yang tidak puas dengan pemerintahan maupun berseberangan dalam haluan politik.

Dan pelaku tindak pidananya tentu juga harus mempunyai kekuatan politik bahkan militer untuk melakukan upaya yang disebut Makar. fikiran yang membentuk pernyataan bahwa konsep atau kinerja pemerintahan yang sedang berkuasa tidak baik dan ada konsep untuk membangun kekuasaan yang lebih baik membuat seorang akan mengeluarkan pendapatnya tersebut agar didengar dan mendapatkan dukungan dari orang atau kelompok lain, sebagaimana sebuah kisah yang diungkapkan bahwa Letkol sjoeib (bersama Kolonel Dahlan Djambek, Letkol Ahmad Husein, dan Mayor Nursyirwan) pernah menerima surat (tertanggal 19 September 1960) yang diketik sendiri oleh Perdana Menteri Muhammad Natsir tentang 
pengalaman masalalunya berhubungan dengan militer, terutama dengan Nasution, dalam suratnya bercerita pernah didatangi oleh Gatot Subroto yang merupakan utusan Nasution, menyampaikan bahwa pimpinan Angkatan Darat menyimpulkan bahwa politisi telah gagal dalam memilihara negara, dan untuk itu jangan kaget jika militer mengambil alih kekuasaan. ${ }^{5}$ Dan untuk itu, mengadili pikiran dan pendapat seseorang hanya karena mempunyai pendapat yang berbeda adalah suatu tindakan pelanggaran HAM, tidak demokratis dan otoriter $^{6}$

Delik Terhadap Kemanan Negara hampir selalu dilatarbelakangi serta/atau dengan tujuan-tujuan politik dan setiap-setiap pemerintahan suatu Negara mempunyai pengertian serta batasan tersendiri tentang perbuatan-perbuatan yang dikategorikan sebagai mempunyai latar belakang serta tujuan politik, dan bahkan terdapat perbedaan penafsiran terhadap pengertian 'politik' baik dikalangan sarjana, para hakim, maupun penguasa suatu Negara. ${ }^{7}$

Kemudian terkait dengan hal tersebut di atas, Mardjono Reksodiputro di dalam bukunya menyebutkan bahwa, Inti dari perbuatan yang di larang dalam Bab-I (dari Buku II) KUHP tersebut adalah 'Makar' (treason; verraad), perbuatan mana yang dimaksud dikategorikan sebagai "usaha pengkhianatan terhadap negara dan bangsa".

Dengan melihat tujuan dari Bab I Buku Kedua yang maksudnya adalah untuk menjaga keamanan negara maka, ketika hukum pidana bersinggungan antara kepentingan

${ }^{5}$ Moh. Mahfud MD, Perdebatan Hukum Tata Negara, (Jakarta: Rajawali Pers, 2011). 83-84

6 Achmad Ali, 2009, Menguak Teori Hukum..., 488

7 Loebby Loqman, Delik Politik di Indonesia, (Jakarta: Ind-Hill-Co, 1993). 7

${ }^{8}$ Mardjono Reksodiputro, Pembaharuan Hukum Pidana (Kumpulan Karangan), vol. IV (Jakarta: Pusat Pelayanan Keadilan dan Pengabdian Hukum Universitas Indonesia, 2007). 115 kekuasaan dengan hak-hak warga negara, maka ini merupakan hal yang sangat sensitif sifatnya. Belum jelas kategorisasi mana yang dapat disebut sebagai tindakan makar/delik terhadap keamanan negara dan kemudian menjadi tarik ulur bagi berbagai kepentingan. Tumpang tindihnya pengertian terhadap perbuatan yang dianggap sebagai Delik Terhadap Keamanan Negara/Makar sering menimbulkan keresahan di dalam suatu masyarakat terutama apabila dihubungkan dengan Hak Asasi Manusia (HAM), yakni hak untuk mengeluarkan pendapat dari warga, hak penentuan nasib sendiri bagi suatu masyarakat, dan hak-hak lainnya, yang terlebih lagi apabila dikaitkan dengan Sistem Demokrasi di sebuah Negara. ${ }^{9}$

\section{TINJAUAN UMUM TERHADAP KEMERDEKAAN MENYAMPAIKAN PENDAPAT DAN MAKAR}

Dinyatakan pada bagian Penjelasan dari Undang-Undang Nomor 9 Tahun 1998 Tentang Kemerdekaan Menyampaikan Pendapat Di Muka Umum yang menyatakan bahwa perwujudan kehendak warga negara secara bebas dalam menyampaikan pikiran secara lisan dan tulisan dan sebagainya harus tetap dipelihara agar seluruh tatanan sosial dan kelembagaan baik infrastruktur maupun suprastruktur tetap terbebas dari penyimpangan atau pelanggaran hukum yang bertentangan dengan maksud, tujuan dan arah dari proses keterbukaan dalam pembentukan dan penegakan hukum sehingga tidak menciptakan disintegrasi sosial, tetapi justru harus dapat menjamin rasa aman dalam kehidupan masyarakat. Dengan demikian, maka kemerdekaan menyampaikan pendapat di muka umum harus dilaksanakan dengan penuh tanggung jawab, sejalan dengan ketentuan peraturan perundang-undangan

9 Anshari, Delik Terbadap Keamanan Negara (Makar) di Indonesia (Suatu Analisis Yuridis Normatif pada Studi Kasus Sultan Hamid II), (Jakarta: Tesis Universitas Indonesia, 2012). 8 
yang berlaku dan prinsip hukum internasional sebagaimana tercantum dalam Pasal 29 Deklarasi Universal Hak Asasi Manusia 1948 (Universal Declaration Of Human Rights 1948) ${ }^{10}$, yang antara lain menetapkan sebagai berikut :

1. Setiap orang memiliki kewajiban terhadap masyarakat yang memungkinkan pengembangan kepribadian secara bebas dan penuh.

2. Dalam pelaksanaan hak kebebasan, setiap orang harus tunduk pada pembatasan yang ditentukan oleh undang-undang dengan maksud untuk menjamin pengakuan dan penghargaan terhadap hak serta kebebasan orang lain, untuk memenuhi syarat-syarat yang adil bagi moralitas, ketertiban serta kesejahteraan umum dalam suatu masyarakat yang demokratis.

3. Hak dan kebebasan ini sama sekali tidak boleh dijalankan secara bertentangan dengan maksud-maksud dan prinsip-prinsip Perserikatan Bangsa-Bangsa.

Deklarasi Universal Hak Asasi Manusia sebagai permulaan perjuangan moderen untuk melindungi hak-hak asasi manusia, kita dapat menelusuri asal-usul hakhak asasi manusia itu pada teori-teori filsafat tentang 'hukum kodrat', suatu hukum yang lebih tinggi dari pada hukum positif negara. Menurut teori ini, individu sebagai manusia membawa dalam dirinya sendiri sejak lahir hak-hak asasi tertentu yang tidak dapat dihilangkan. ${ }^{11}$

10 Deklarasi (Declaration) seperti misalnya Deklarasi Universal Hak Asasi Manusia 1948 yang dibuat oleh Perserikatan Bangsa-Bangsa (PBB) merupakan salah satu bentuk perjanjian internasional dan merupakan sumber hukum internasional. Perjanjian internasional juga diistilahkan dengan nama lain, seperti: traktat (treaty), pakta (pact), konvensi (convention), piagam (statute), charter, protokol, arrangement, accord, modus vivendi, conenant. Mochtar Kusumaatmadja, Pengantar Hukum Internasional, (Bandung: Bina Cipta, 1976). 111.

${ }^{11}$ David Weissbrodt, Hak-Hak Asasi Manusia: Tinjauan Dari Perspektif Kesejarahan, Jakarta: Yayasan Obor Indonesia). 2.
Dalam konteks hukum internasional hak kemerdekaan menyampaikan pendapat secara bebas dan bertanggung jawab juga diatur pada perjanjian internasional sebagai salah satu instrumen hukum internasional yaitu pada Pasal 19 Konvenan Internasional Hak Sipil Dan Politik 1966 (International Convenant On Civil And Political Rights 1960) ${ }^{12}$, yang menyatakan; 1) Setiap orang barus berbak untuk memiliki opini tanpa intervensi; 2) Setiap orang harus berhak atas kebebasan berekspresi; hak ini harus meliputi kebebasan untuk mencari, menerima serta mengungkapkan segala jenis informasi dan gagasan, terlepas dari garis perbatasan, secara lisan, tulisan atau tercetak, dalam bentuk karya seni, atau melalui segala media lain pilihannya sendiri; 3) Pelaksanaan hak-hak yang dijamin dalam ayat 2 Pasal ini membawa kewajiban-kewajiban dan tanggung jawabtanggung jawab tersendiri. Karenanya hal ini tunduk pada pembatasan-pembatasan tertentu, tetapi ini hanya boleh dilakukan sebagaimana yang ditetapkan oleb bukum dan yang diperlukan untuk menghargai bak atau nama baik orang lain dan untuke melindungi keamanan nasional atau ketertiban umum, atau kesehatan atau kesusilaan umum.

Selain, itu, juga disebutkan dalam Deklarasi Kebebasan Berpendapat di Kairo. ${ }^{13}$ Kemerdekaan menyatakan pendapat ini adalah implementasi dari nilai-nilai hak asasi manusia.

${ }^{12}$ Konvenan Internasional Hak-Hak Sipil Dan Politik 1966 (International Convenant On Civil And Political Rights 1966) telah diratifikasi oleh Indonesia dengan Undang-Undang Nomor 12 Tahun 2005. Istilah kovenan (covenant) sama dengan treaties yang berarti perjanjian internasional yang merupakan international agreements yang menimbulkan hak dan kewajiban hukum bagi negara yang telah meratifikasi perjanjian international tersebut. Seperti dinyatakan oleh Mark W. Janis: International agreements, like private contracts, are something more than statements of expected future conduct. Treaties create legal rights and duties, and it is this obligatory aspect that makes them part of international law. Dalam Mark W. Janis, An Introduction to International Law, New York: Aspen Publishers, 2003). 9.

13 Abd Rahman, "Kebebasan Berpendapat: Tinjauan Filosofis Pasal 22 Deklarasi Kairo tentang HakAsasi Manusia dalam Islam," Alhurriyah: Jurnal Hukum Islam 3, no. 1 (June 22, 2018): 81-94-94, doi:10.30983/alhurriyah.v3i1.531. 
Seperti ditulis oleh James W. Nickel dalam bukunya yang berjudul Making Sense Of Human Rights menyatakan bahwa ketika hak asasi manusia diimplementasikan didalam hukum internasional, kita masih menyebutnya sebagai hak asasi manusia; namun manakala itu diimplementasikan didalam hukum domestik, kita condong menggambarkannya sebagai hak sipil atau hak konstitusional. ${ }^{14} \mathrm{Hak}$ asasi manusia (HAM) dalam hukum nasional Indonesia telah diatur pada Perubahan Kedua UUD 1945. Muatan HAM dalam Perubahan Kedua UUD 1945 dapat dikatakan sebagai bentuk komitmen jaminan konstitusi atas penegakan hukum dan HAM di Indonesia. ${ }^{15}$ Dalam konteks hukum nasional (hukum domestik) Indonesia maka hak konstitusional warga negara tentang hak kemerdekaan menyampaikan pendapat telah diatur secara jelas dalam Konstitusi Negara Republik Indonesia yaitu Undang-Undang Dasar 1945 (Perubahan Kedua UUD 1945), yaitu pada pasal-pasal sebagai berikut:

$$
\text { Pasal 28E Ayat (2) UUD } 1945
$$

menyatakan:

Setiap orang berbak atas kebebasan meyakini kepercayaan, menyatakan pikiran dan sikap, sesuai dengan hati nuraninya.

Pasal 28E Ayat (3) UUD 1945 menyatakan:

Setiap orang berhak atas kebebasan berserikat, berkumpul, dan mengeluarkan pendapat.

Demikian juga Pasal 25 UndangUndang Nomor 39 Tahun 1999 Tentang Hak Asasi Manusia menyatakan:

Setiap orang berbak untuk menyampaikan pendapat di muka umum, termasuk bake

${ }^{14}$ James W. Nickel, Hak Asasi Manusia, Refleksi Filosofis Atas Deklarasi Universal Hak Asasi Manusia, judul asli: Making Sense Of Human Rights, Philosophical Reflection on the Universal Declaration of Human Rights, Terj. Titis Eddy Arini, Jakarta: Gramedia Pustaka Utama, 1996). 55.

${ }^{15}$ Majda El-Muhtaj, Hak Asasi Manusia Dalam Konstitusi Indonesia, Jakarta: Kencana Prenada Media Group, 2005). 113. untuk mogok sesuai dengan ketentuan peraturan perundang-undangan.

Salah satu prinsip negara hukum sebagaimana disebutkan adalah perlindungan Hak Asasi Manusia (HAM). Terkait hal ini, Indonesia mengalami banyak kemajuan bidang Hak Asasi Manusia setelah reformasi, yaitu amandemen UUD 1945, lahirnya beberapa peraturan perundang-undangan termasuk melalui ratifikasi Kovenan Internasional yang menjamin dan melindungi Hak Asasi Manusia, diantaranya Undang-Undang Nomor 11 Tahun 2005 tentang Ratifikasi Kovenan Internasional Hak-Hak Ekonomi, Sosial, dan Budaya (International Covenan on Economic, Social and Cultural Rights/ ICESCR), Undang-Undang Nomor 12 Tahun 2005 tentang Ratifikasi Kovenan Internasional Hak-Hak Sipil dan Politik (International Covenan on Civil and Political Rights/ ICCPR), Undang-Undang Nomor 39 Tahun 1999 Tentang Hak Asasi Manusia;

Selanjutnya UU Nomor 39 Tahun 1999 juga mengatur hal yang sama sebagaimana dimaksud dalam Pasal 71 dan Pasal 72. Pasal 71 berbunyi,

"Pemerintab wajib dan bertanggung jawab menghormati, melindungi, menegakekan, dan memajukan hak asasi manusia yang diatur dalam undang-undang ini, peraturan perundang-undangan lain, dan bukum internasional tentang hak asasi manusia yang diterima oleb negara Republik Indonesia”.

Pasal 72 menyebutkan,

"Kewajiban dan tanggung jawab pemerintah sebagaimana dimaksud dalam Pasal 71, meliputi langkah-langkah implementasi yang efektif dalam bidang bukum, politik, ekonomi, sosial, budaya, pertahanan keamanan negara, dan bidang lain";

Tanggung jawab negara berkaitan dengan Hak Asasi Manusia (HAM) adalah melindungi (to protect), menghormati (to respect), dan memenuhi (to fulfill) Hak Asasi warga negara baik hak-hak sipil dan politik maupun hak-hak ekonomi, sosial budaya seperti hak atas pekerjaan, hak atas hidup layak, hak atas pendidikan, hak atas kebebasan atas perlakuan 
yang bersifat diskriminatif, hak atas persamaan di depan hukum, hak atas pengakuan, jaminan, perlindungan, dan kepastian hukum yang adil serta perlakuan yang sama dihadapan hukum, hak untuk hidup, dan hak-hak lainnya. Pemenuhan Hak Asasi Manusia itulah yang sebenarnya tujuan pokok dan utama dibentuknya negara yang merupakan tanggung jawab negara memenuhinya.

Konsep negara ini diusung oleh John Locke yang menyatakan bahwa negara ada dan dibentuk oleh manusia semata-mata untuk menjamin perlindungan hak-hak milik manusia yakni kehidupannya, kebebasannya, dan hak miliknya. Hak-hak milik yang melekat pada manusia inilah yang kemudian diartikan sebagai hak asasi manusia, karena hak tersebut memang dimiliki oleh manusia sejak lahir. Inilah yang menjadi pemikiran Locke mengenai kaitan antara hak-hak manusia dengan negara. Negara ada, melalui perjanjian di antara manusia, untuk menjaga hak-hak manusia itu. Selain menjadi tujuan, hal ini juga menjadi dasar dari alasan adanya negara. Oleh sebab itu, "the preservation of human's property" ini merupakan "raison d'etre" dari negara) ${ }^{16}$;

Dengan diterapkannya prinsip negara hukum di Indonesia, Jimly Asshiddiqie menjelaskan paling tidak sedikitnya terdapat 12 (dua belas) prinsip pokok negara hukum yang berlaku di zaman sekarang ini, dan dapat diterapkan di Indoenesia, Keseluruhannya merupakan pilar utama yang menyangga berdiri tegaknya suatu negara yang demokratis konstitusional, sehingga dapat disebut sebagai Negara Hukum dalam arti yang sebenarnya. Kedua belas prinsip pokok tersebut meliputi: a. supremasi hukum (supremasi of law); b. persamaan dalam hukum (equality before the law); c. asas legalitas (due process of (aw); d. pembatasan kekuasaan (limitation of power); e. organ-organ eksekutif yang bersifat

${ }^{16}$ LG. Saraswati dan Taufik Basari, dkk, Hak Asasi Manusia, Teori, Hukum, Kasus, (Jakarta: UI Press, 2006). 194-195 independen (independent executive organ); $\mathrm{f}$. peradilan yang bebas dan tidak memihak (impartial and independent judiciary); g. peradilan tata usaha negara (administrative court); $\mathrm{h}$. peradilan tata negara (constitusional court); i. perlindungan hak asasi manusia (buman rights protection); j. bersifat demokratis (democratische rechstaat); k. berfungsi sebagai sarana mewujudkan tujuan kesejahteraan (welfare rechtsstaat); i. transparansi dan kontrol sosial (tranparency and social controb)

Berdasarkan ketentuan Pasal 1 ayat (3) tersebut, Indonesia merupakan salah satu negara dari sekian banyak negara yang menganut negara hukum, dimana penyelenggaraan kekuasaan negara dan pemerintahan dibatasi oleh konstitusi. Adanya pembatasan kekuasaan, merupakan faktor pendukung dari prinsip-prinsip negara hukum dan demokrasi lainnya, yaitu hak asasi manusia. Hak asasi manusia di Indonesia yang berkaitan dengan penyelenggaraan pemerintahan, tertuang di dalam Pasal 28 Undang- Undang Dasar 1945. Di dalam Pasal tersebut segala hak yang berkaitan eksistensi dan aktivitas warga negara dijamin dan dilindungi Konstitusi dan peraturan perundang-undangan dibawahnya; oleh karenanya, karena Indonesia menganut negara hukum yang dibatasi konstitusi, maka penyelenggaraan kekuasaan negara dan pemerintahan harus didasarkan atas dasar hukum yang baik dan adil. Hukum menjadi landasan dari segenap tindakan negara, dan hukum itu sendiri harus baik dan adil. Baik karena sesuai dengan apa yang diharapkan oleh masyarakat dari hukum, dan adil karena maksud dasar segenap hukum adalah keadilan ${ }^{18}$; Selain itu, segala kewenangan dan tindakan alat-alat perlengkapan negara harus

17 Jimly Asshiddiqie, Gagasan Negara Hukum Indonesia, 8-17

${ }^{18}$ Frans Magnis Suseno, Etika Politik Prinsipprinsip Moral Dasar Kenegaraan Modern, Jakarta: Gramedia,1994). 29 
pula berdasarkan dan diatur oleh hukum. Penguasa bukanlah pembentuk hukum, melainkan pembentuk aturan-aturan hukum, oleh sebab itu hukum berlaku bukan karena ditetapkan oleh penguasa, akan tetapi karena hukum itu sendiri. Hal ini membawa konsekuensi, bahwa penguasa pun dapat dimintai pertanggungjawaban jika dalam menjalankan kekuasaannya melampaui batasbatas yang telah diatur oleh hukum, atau melakukan perbuatan melawan hukum.

Kewenangan penguasa dan organorgan negara sangat dibatasi kewenangan perseorangan dalam negara, yang berupa hak asasi manusia. Pendapat tersebut menegaskan bahwa hak asasi manusia merupakan unsur penting dalam sebuah negara hukum; dengan kata lain, aturan perundangan-undangan yang tercipta, harus berisi nilai-nilai keadilan bagi semua orang. Sehingga, akan menunjukkan bahwa negara hukum yang dianut Indonesia akan menjamin keadilan substanstif (the rule of law). Tidak sekedar memfungsikan peraturan perundang-undangan. Berdasarkan the rule of law, seluruh peraturan perundang- undangan harus dapat dimaknai sebagai " a legal system in which rules are clear, well-understood, and fairly enforced'- - sebuah sistem hukum yang jelas (kecil kemungkinan untuk disalahgunakan), mudah dipahami, dan menjaga tegaknya keadilan. Kepastian hukum menjadi salah ciri the rule of law, yang di dalamnya mengandung asas legalitas, prediktibilitas, dan transparans; Kepastian hukum dan perlakuan yang sama di muka hukum merupakan salah satu ciri pokok dari negara hukum atau the rule of law sebagaimana dinyatakan dalam Pasal 1 ayat (3) UUD 1945 yang menyatakan bahwa "Negara Indonesia adalah negara hukum", dimana kepastian hukum merupakan prasyarat yang tidak bisa ditiadakan dari Negara hukum; Asas kepastian hukum menjadi salah ciri dari negara hukum—the rule of law, yang di dalamnya mengandung asas legalitas, prediktibilitas, dan transparansi. Sebagaimana diketahui bahwa ciri-ciri negara hukum adalah, "a legal system in which rules are clear, well-understood, and fairly enforced';

Kepastian hukum (certainty), salah satunya mengandung pengertian bahwa hukum haruslah dapat diprediksi, atau memenuhi unsur prediktibilitas, sehingga seorang subjek hukum dapat memperkirakan peraturan apa yang mendasari perilaku mereka, dan bagaimana aturan tersebut ditafsirkan dan dilaksanakan;

Menurut B. Arief Sidharta menjelaskan kepastian hukum dalam suatu Negara Hukum adalah terdapatnya kejelasan hukum dalam tatanan masyarakat. hukum bertujuan mewujudkan prediktabilitas yang tinggi, sehingga dinamika kehidupan bersama dalam masyarakat bersifat 'predictable'. Kepastian hukum secara normatif adalah ketika suatu peraturan dibuat dan diundangkan secara pasti karena mengatur secara jelas dan logis dalam artian tidak menimbulkan keragu-raguan (multi- tafsir), dan logis dalam arti menjadi sistem norma dengan norma yang lain sehingga tidak berbenturan atau menimbulkan konflik norma yang ditimbulkan dari ketidakpastian $^{19}$;

Menurut Gustav Radbruch, cita hukum (Idee des Rechts)—yang dilembagakan dalam suatu bentuk negara hukum, harus memenuhi tiga prinsip umum, yaitu: purposiveness_kemanfaatan (Zweckmassigkeit), justice-keadilan (Gerechtigkeit), dan legal certainty-kepastian hukum (Rechtssicherheit). Ketiga unsur tersebut haruslah terdapat dalam hukum, baik undang-undang maupun putusan hakim, secara proporsional atau berimbang, jangan sampai salah satu unsurnya tidak terakomodasi, atau satu mendominasi yang

${ }^{19}$ B. Arief Sidharta, "Kajian Kefilsafatan tentang Negara Hukum", Jentera (Jurnal Hukum) Rule of Law Pusat Studi Hukum dan Kebijakan (PSHK), vol. II no. 3, Jakarta: November, 2004). 124-125 
lain ${ }^{20}$, Lebih lanjut Radbruch menjelaskan, untuk membuat hukum yang benar- benar proporsional, sesungguhnya sangatlah sulit, karena cita hukum yang satu dengan yang lain, pada dasarnya memiliki nilai-nilai yang saling bertentangan-kontradiksi (antinomi), misalnya antara kepastian dan keadilan. Oleh karenanya, hukum yang berlaku dalam suatu masyarakat hukum, haruslah perimbangan dari beragam pertentangan - antinomi, seperti halnya formulasi antara kepastian hukum, kemanfaatan, dan keadilan;

Oleh karenanya, setiap pembentukan hukum yang adil harus memperhatikan prinsip-prinsip yang dapat menjamin kepastian, kemanfaatan dan keadilan diantaranya yaitu:

1. Hukum-hukum harus dibuat sedemikian rupa sehingga dapat dimengerti oleh rakyat biasa. Fuller juga menamakan hal ini juga sebagai hasrat untuk kejelasan;

2. Aturan-aturan tidak boleh bertentangan satu sama lain;

3. Dalam hukum harus ada ketegasan. Hukum tidak boleh diubah-ubah setiap waktu, sehingga setiap orang tidak lagi mengorientasikan kegiatannya kepadanya;

4. Harus ada konsistensi antara aturan-aturan sebagaimana yang diumumkan dengan pelaksanaan senyatanya.

Apabila ketentuan-ketentuan yang saling bertentangan dan kontradiktif (antinomi) masih tetap diberlakukan, seringkali mengakibatkan ketidak- pastian hukum bagi semua orang. Ketidakpastian demikian akan mengakibatkan kekacauan hukum dan sangat rentan akan adanya penyalahgunaan dan pemberlakuan secara sewenang-wenang, Menurut Jan Remmelink syarat lex certa (undang-undang yang dirumuskan terperinci dan cermat) sering dikaitkan dengan kewajiban pembuat undang-undang untuk merumuskan

20 Sudikno Mertokusumo, Penemuan Hukum Sebuah Pengantar, (Yogyakarta: Cahaya Atma Pustaka, 2009). 92 suatu ketentuan pidana. Lebih lanjut dikatakan bahwa perumusan ketentuan pidana yang tidak jelas atau terlalu rumit hanya akan memunculkan ketidakpastian hukum ${ }^{21}$;

\section{KEMERDEKAAN MENYAMPAIKAN PENDAPAT SEBAGAIMANA MAKAR DALAM KUHP}

Dalam KUHP tidak ditemukan definisi atau pengertian makar itu sendiri, maka penulis merujuk pengertian makar berdasarkan pendapat dari para sarjana serta merunut kembali berdasarkan asal muasal lahirnya KUHP yang merupakan konkordansi dari memorie van toelichting (MvT)untuk menentukan apa yang dimaksud dengan makar tersebut, secara gramatikal akan penulis uraiakan, serta untuk mendapatkan pengertian itu juga ditinjau dari karakteristik dari makar tersebut sebagaimana dalam KUHP.

Pengertian Makar

Dengan ketidak-adaan KUHP mendefinisikan dan memberikan pijakan yang tepat terhadap pengertian "Makar" tentu akan melanggengkan situasi ketidak pastian hukum dan hilangnya jaminan perlindungan hukum bagi warga negara Indonesia, lebih dari itu mengakibatkan tidak terwujudnya reformasi hukum pidana yang berkeadilan, dengan demikian penulis mencoba menemukan pegertian makar berdasarkan pendapat para sarjana, diantaranya;

Menurut Djoko Prakoso, "Makar" merupakan terjemahan dari kata "Aanslag" yang berarti "Serangan". KUHP kita tidak memberikan definisinya namun hanya penafsiran yang otentik (khusus) yang terdapat dalam Pasal 87 KUHP. ${ }^{22}$

Menurut Lamintang, jika dihubungkan dengan tindak pidana yang diatur dalam Pasal

${ }^{21}$ Jan Remmelink, Hukum Pidana: Komentar atas Pasal-Pasal Terpenting Dari KUHP Belanda dan Padanannya Dalam KUHP Indoenesia, 2003.

${ }^{22}$ Djoko Prakoso, Tindak Pidana Makar Manurut KUHP, (Jakarta: Ghalia Indonesia, 1985). 65 
104 KUHP kiranya “Aanslag” hanya tepat diartikan sebagai aanval (serangan) atau sebagai misadadige aanranding (penyerangan dengan maksud tidak baik) ${ }^{23}$

Dan Menurut Wirjono Prodjodikoro ${ }^{24}$ juga menggunakan kata "Makar" sebagai terjemahan kata "Aanslag", yang menurut beliau adalah "Serangan". Sehingga dapat dipahami bahwa menurut Wirjono Prodjodikoro, "Aanslag" adalah "Serangan."

R. Soesilo dalam komentarnya terkait KUHP, disebutkan bahwa "aanslag (makar atau penyerangan) itu biasanya dilakukan dengan perbuatan kekerasan". Bahwa kemudian perbuatan makar (aanslag) ditujukan tergantung pada tujuan yang tercantum pada pasal, misalnya Pasal 104 yaitu melakukan "penyerangan dengan perbuatan kekerasan dengan niat hendak membunuh atau merampas kemerdekaan atau menjadikan tidak cakap memerintah Presiden atau Wakil Presiden; ${ }^{25}$ secara konsisten memberikan komentar terkait delik-delik Makar sesuai pemahaman Makar sebagai serangan dengan kekerasan, komentar dalam pasal lain misalnya dalam Pasal 107 KUHP, R. Soesilo berkomentar bahwa Pasal 107 KUHP adalah melakukan "penyerangan dengan perbuatan kekerasan dengan maksud dari penyerangan ini adalah menggulingkan pemerintahan; ${ }^{26}$

Andi Hamzah yang menyebutkan, "Aanslag sebagai percobaan membunuh." Lebih lanjut Andi Hamzah menjelaskan bahwa percobaan membunuh ini pada awalnya ditujukan kepada raja, namun dalam konteks sekarang dapat ditujukan kepada presiden. ${ }^{27}$

${ }^{23}$ P. A. F Lamintang dan Theo Lamintang, Delik-Delik Khusus Kejahatan terhadap Kepentingan Hukum Negara, (Jakarta: Sinar Grafika, 2010). 7

${ }^{24}$ Djoko Prakoso, Tindak Pidana Makar..., 15

${ }^{25}$ R.Soesilo, Kitap Undang-Undang Hukum Pidana (KUHP) Serta Komentar komentarnya Lengkap Pasal demi Pasal, (Bogor: Politea, 1996). 108

${ }^{26}$ Ibid, 109

27 Andi Hamzah, Delik- delik Tertentu (Speciale Delicten) di Dalam KUHP, (Jakarta: Sinar Grafika, 2015). 215
Kemudian Prof. Noyon dan Prof. Langemeijer, mendifinisikan makar sebagaimana berikut; kebanyakan “Aanslag” merupakan tindak kekerasan atau setidaktidaknya merupakan percobaan- percobaan untuk melakukan tindak kekerasan. ${ }^{28}$

Sedangkan Adami Chazawi menyebut Makar (aanslag) adalah perbuatan yang ditujukan untuk menggulingkan pemerintahan (omwenteling), dimana dalam perbendaharaan hukum pidana telah lazim diterjemahkan dengan kata Makar.

Eddy O.S Hiariaje berpendapat; adagium terkait dengan delik - delik makar menyatakan felonia implicatur in quolibet proditione yang artinya, perbuatan makar termasuk tindak pidana yang tergolong berat. Oleh karena itu, makar bukanlah delik percobaan yang dirumuskan sebagai delik selesai atau delik berdiri sendiri, melainkan delik makar dirumuskan demikian karena bertalian dengan keamanan negara yang menyangkut keselamatan presiden dan wakil presiden, rongrongan terhadap pemerintahan yang sah dan kedaulatan negara. ${ }^{29}$

Seperti disebutkan bahwa delik terhadap keamanan Negara diatur dalam Bab I Buku II mulai dari Pasal 104 sampai dengan Pasal 129 KUHP. Pembagian atau pengelompokan jenis delik ini adalah sebagai berikut: ${ }^{30}$

1. Penghianatan Intern (Hoogverrad) yang terdiri dari Pasal 104 sampai dengan Pasal 110 KUHP;

2. Penghianatan Ekstern (Landverrad) yang terdiri dari Pasal 111 sampai dengan Pasal 129 KUHP.

Namun disini penulis hanya melihat dari sudut penghianatan intern saja, untuk

${ }^{28}$ P. A. F Lamintang dan Theo Lamintang, Delik-delik Khusus..., 10

29 Eddy O.S Hiariaje, Prinsip-Prinsip Hukum Pidana, (Yogyakarta: Cahaya Atma Pustaka). 2016, 327

30 Wirjono Prodjodikoro, Tindak-tindak Pidana Tertentu di Indonesia, (Bandung: Eresco, 1986). 193-194. 
mempersempit dalam tinjauan kepada kemerdekaan menyampaikan pendapat dimuka umum:

Penghianatan Intern yaitu kejahatan terhadap bentuk pemerintahan dan bentuk negara. Hai ini sebagaimana yang dikemukakan dalam Bab I Buku II dari Pasal 104. Dalam hal ini yang dilanggar adalah keamanan intern Negara (inwindige velligheid) atau "internal security", yang perinciannya sebagai berikut: ${ }^{31}$ Pasal 104 KUHP

Dalam Pasal 104 KUHP diatur mengenai Delik Makar yang dilakukan untuk menghilangkan nyawa atau kemerdekaan Presiden dan Wakil Presiden, yang pada mulanya telah diatur dalam Pasal 104 Wetboek van Strafrecht, yang rumusannya dalam bahasa Belanda berbunyi sebagai berikut:

"De aanslag ondernomen met het oogmerk. om den Koning, de regeerende Koningin of den Regent van het leven of de vrijheid te berooven of tot regeeren ongeschikt te maken, wordt gestraft met de doodstraf of levenslange gevangenisstraf of tijdelijke van ten hoogste twintig jaren". 32

Artinya:

"Makar (aanslag) jang dilakoekan dengan maksoed (niat) hendak memboenoeh Baginda Radja, Baginda Ratoe (Radja perempoean) atau Regent, atau dengan niat hendak merampas kemerdekaan mereka itoe atau hendak mendjadikan mereka itoe tiada sanggoep memerintah, dihoekoem mati atau pendjara seoemoer hidoep atau pendjara sementara selama-lamanja doea poeloeh tahoen". ${ }^{33}$

Menurut ketentuan yang diatur dalam Pasal VIII angka 12 Undang-undang Nomor 1

${ }^{31}$ Sumber pasal-pasal dimaksud berasal dari KUHP terjemahan resmi BPHN dalam KUHAP dan KUHP, (Jakarta: Sinar Grafika, 2000). 38-46

32 Kitab Oendang-oendang Hoekoeman Bagi Hindia Belanda - Wetboek van Strafrecht voor Nederlandsch Indie, (Batavia-C: Balai Poestaka, 1940). 68

$$
{ }^{33} \text { Ibid, } 69
$$

tanggal 26 Februari tahun 1946, berita Republik Indonesia II, kata-kata den Koning, de regeerende Koningin of den Regent dalam rumusan Pasal 104 Wetboek van Srafrecht di atas diganti dengan kata-kata den President of den VicePresident, sehingga rumusan Pasal 104 Wetboek van Strafrecht atau Pasal 104 Kitab Undangundang Hukum Pidana yang berbunyi sebagai berikut:

"De aanslag ondernomen met het oogmerk om den President of den Vice-President van bet leven of de vrijheid te berooven of tot regeeren ongeschikt te maken, wordt gestraft met de doodstraf of levenslange gevangenisstraf of tijdelijke van ten hoogste twintig jaren".

Artinya:

"Makar yang dilakukan dengan maksud untuk menghilangkan nyawa, atau merampas kemerdekaan, atau meniadakan kemampuan Presiden atau Wakil Presiden menjalankan pemerintahan, diancam dengan pidana mati atau penjara seumur hidup atau pidana penjara sementara paling lama 20 (dua puluh) tahun".

Jika delik yang dirumuskan dalam Pasal 104 KUHP tersebut di jabarkan dalam unsurunsur, maka akan diketahui bahwa delik yang diatur dalam Pasal 104 KUHP memiliki unsurunsur sebagai berikut:

1. Makar;

Melakukan perbuatan makar ditafsirkan secara otentik dalam Pasal 87 KUHP yaitu "Dikatakan ada makar untuk melakukan suatu perbuatan, apabila niat untuk itu telah ternyata dan adanya permulaan pelaksanaan seperti dimaksud dalam Pasal 53". Makar dapat diartikan juga dengan serangan atau penyerangan dengan maksud tidak baik.

Suatu perbuatan dapat dinyatakan sebagai perbuatan Makar, apabila perbuatan permulaan pelaksanaan merupakan perwujudan niat dan pelaku, sesuai dalam arti Pasal 53, yaitu percobaan melakukan kejahatan yang dapat dihukum. Pasal 53 menentukan secara eksplisit, bahwa 
perbuatan percobaan itu tidak dapat dihukum apabila pelaksanaan kehendak itu terhenti karena keinginan sendiri secara sukarela. Namun dalam Pasal 104 perbuatan Makar tetap dapat dihukum meskipun pelaksanaan kehendaknya terhenti karena keinginan sendiri secara sukarela. Dalam melakukan makar ini tersirat suatu perbuatan berencana. Tetapi pembuat undang-undang tidak bermaksud demikian, tidak hanya makar dengan perbuatan berencana namun bahkan makar (serangan) paling ringan saja sudah merupakan bahaya bagi keamanan Negara, hingga ancaman hukuman yang terberat terhadap perbuatan makar itu sudah dapat dipertanggungjawabkan menurut keadilan. ${ }^{34}$ Ada pendapat bahwa makar jangan diartikan atau di identikkan dengan suatu tindak kekerasan saja karena tindakan makar sebenarnya ialah segala tindakan yang dilakukan untuk merugikan kepentingan-kepentingan hukum tertentu dari Presiden dan Wakil Presiden.

Menurut Noyon-Langemeijer: "kebanyakan aanslag atau makar merupakan tindakan kekerasan atau setidak- tidaknya percobaan-percobaan untuk melakukan tindak kekerasan seperti itu, namun tidak setiap makar harus diartikan dengan tindakan kekerasan, karena dalam praktek juga dijumpai beberapa makar yang dapat dilakukan orang tanpa melakukan suatu tindak kekerasan, misalnya makar untuk mengubah bentuk pemerintahan yang sah, dimana makar tersebut hanya merupakan suatu cara untuk mencapai suatu tujuan tertentu". 35

Makar dengan maksud adalah percobaan yang tidak sah. Makar merupakan perbuatan yang tidak sah sama

${ }^{34}$ H.A.K Moch. Anwar, Hukum Pidana Bagian Khusus, (Bandung: Alumni, 1982). 218

${ }^{35}$ P. A. F Lamintang dan Theo Lamintang, Delik-delik Khusus.... 9 sekali dengan tujuan untuk mencapai sesuatu yang tidak sah. Perbuatan Makar yang merupakan perbuatan percobaan dalam pengertian Pasal 53 KUHP yang dijadikan kejahatan yang berdiri sendiri dan dinyatakan sebagai kejahatan yang sempurna.

Dikarenakan sebagian pendapat mensyaratkan keharusan dilakukannya suatu permulaan pelaksanaan oleh pelaku untuk menyelesaikan makar, maka apakah mungkin seseorang dituntut karena percobaan melakukan makar (misal makar menurut Pasal 104 KUHP), mengingat bahwa untuk adanya suatu percobaan yang dapat dipidana dalam pasal 53 ayat (1) KUHP, pembentuk Undang-undang telah mensyaratkan bahwa pelaku harus sudah mewujudkan maksudnya dalam suatu permulaan pelaksanaan. ${ }^{36}$

Menurut Lamintang, terhadap seseorang itu tidak mungkin dikenakan dakwaan telah mencoba melakukan makar atau didakwa, melanggar Pasal 53 ayat (1) jo. Pasal 104 KUHP, karena dengan dilakukannya permulaan pelaksanaan dan tindak pidana yang diatur dalam Pasal 104 KUHP itu sendiri, maka tindak pidana makar seperti yang dimaksudkan dalam Pasal 104 KUHP itu dengan sendirinya harus dianggap telah selesai dilakukan oleh orang tersebut. Hal ini sejalan dengan pendapat Van Bemmelen, ${ }^{37}$ yang menyatakan bahwa pada makar itu tindak pidananya sendiri merupakan suatu tindakan pelaksanaan seperti yang dimaksudkan dalam Pasal 53 ayat (1) KUHP, maka tidak mungkin terdapat suatu percobaan untuk melakukan suatu makar. ${ }^{38}$

${ }^{36}$ Wirjono Prodjodikoro, Tindak-tindak Pidana Tertentu..., 105- 107

${ }^{37}$ Ibid

${ }^{38}$ P. A. F Lamintang dan Theo Lamintang, Delik-delik Khusus..., 16 
Namun kembali Wirjono Prodjodikoro mengemukakan pandangannya yang berbeda yaitu: "ada kemungkinan dilakukan percobaan (poging) untuk makar dari Pasal 104, Jadi, dalam hal makar untuk membunuh Kepala Negara, Perbuatan si pelaku yang baru merupakan perbuatan persiapan untuk tindak pidana pembunuhan biasa. sudah dapat merupakan permulaan pelaksanaan dari tindak pidana makar untuk membunuh Kepala Negara". ${ }^{39}$

Jadi menurut pendapatnya, ada percobaan terhadap makar namun hal itu, menurut Penulis terbatas pada Makar dalam Pasal 104, karena inti perbuatan makar dalam pasal tersebut adalah membunuh Presiden. Jadi percobaan membunuh (Presiden) adalah dapat dipidana dikaitkan dengan tindakan makar tersebut.

Jadi, dapat disimpulkan bahwa perbuatan makar oleh pembuat undangundang tidak hanya dimaksudkan dengan tindakan kekerasan atau anarki namun tindakan diluar itupun jika itu ditujukan kepada kepentingan yang membahayakan keamanan Negara, bahkan percobaan makar dalam membunuh Presiden dapat dipidana dan sudah merupakan bahaya yang harus dicegah dengan sanksi pidana yang maksimum.

2. Dengan Maksud;

Unsur ini adalah unsur subjektif dari pasal ini yang berarti pelaku mempunyai niat atau kehendak atau bertujuan, hingga tujuan tersebut tidak perlu telah terlaksana. Maksud itu harus meliputi perbuatan menghilangkan jiwa, merampas kemerdekaan atau menjadikan tidak mampu menjalankan pemerintahan atas Presiden atau Wakil Presiden.

3. Untuk Menghilangkan Nyawa;

39 Wirjono Prodjodikoro, Tindak-tindak Pidana Tertentu..., 195-196
Menghilangkan nyawa terdiri atas pembunuhan (Pasal 338) dan pembunuhan dengan berencana (Pasal 340) dan perbuatan percobaan atas kedua jenis kejahatan tersebut.

Menurut Noyon-Langemeijer, tidak semua kesengajaan menghilangkan nyawa Presiden dan Wakil Presiden itu dapat dimaksudkan dalam pengertian tindak pidana makar seperti yang dimaksudkan dalam Pasal 104 KUHP, terutama jika meninggalnya Presiden atau Wakil Presiden itu merupakan suatu akibat tidak langsung dari suatu perbuatan yang telah dilakukan oleh seseorang. ${ }^{40}$

Dalam hal ini, perbuatan pelaksanaan dapat masih berupa perbuatan yang secara formil belum selesai atau sedemikian jauh dari sempurna sehingga sudah merupakan perbuatan selesai namun tidak menimbulkan akibat yang dituju (dalam kejahatan materiil). Dimana perbuatan yang sempurna adalah menimbulkan matinya korban (Pasal 338), namun karena sesuatu faktor atau hal yang diluar kekuasaan si pelaku tidak menimbulkan akibat matinya sasaran yang dituju. Dalam hal ini dapat diambil contoh Peristiwa Cikini tanggal 30 November 1957 di Jakarta dimana perbuatan melempar granat telah dilakukan terhadap Presiden Soekarno, namun ada faktor yang diluar kemampuan si pelaku, sehingga tidak menimbulkan kematian pada yang dituju. Jika peristiwa itu dipandang sebagai pembunuhan maka hal itu adalah percobaan pembunuhan. Namun jika dipandang dari kejahatan terhadap keamanan Negara, karena korbannya adalah Presiden, maka peristiwa itu bukan percobaan pembunuhan, melainkan berupa kejahatan selesai yakni kejahatan makar. ${ }^{41}$

${ }^{40}$ P. A. F Lamintang dan Theo Lamintang, Delik-delik Khusus..., 26

${ }^{41}$ Adami Chazawi, Kejahatan Terhadap Kezaliman, 


\section{Untuk Merampas Kemerdekaan;}

Merampas kemerdekaan harus dilihat menurut Pasal 333 KUHP, namun Pasal 333 memuat 2 tindakan yaitu merampas kemerdekaan dan melanjutkan perampasan kemerdekaan itu, sedangkan Pasal 104 hanya memuat tindakan yang meniadakan kebebasan, berhubung tindakan melanjutkan peniadaan kebebasan tidak dapat dihubungkan dengan makar yang bertujuan untuk melaksanakan sesuatu yang belum ada.

Menurut Van Hattum, kemerdekaan disini merupakan semacam kemerdekaan bergerak. Hambatan terhadap kemerdekaan bergerak tersebut bukan hanya dapat dicapai semata-mata dengan penutupan dan pengangkutan secara tidak bebas, melainkan juga dapat dicapai dengan pemaksaan secara psikis, yakni jika karena pemaksaan tersebut seseorang menjadi dihambat dalam kebebasan untuk bergerak. ${ }^{42}$

Dari uraian tersebut jelas bahwa yang dimaksud dengan makar yang dilakukan dengan maksud untuk merampas kemerdekaan Presiden atau Wakil Presiden dalam rumusan Pasal 104 KUHP itu sebenamya adalah makar yang dilakukan dengan maksud untuk merampas kebebasan bergerak dari Presiden atau Wakil Presiden.

5. Untuk Meniadakan Kemampuan Menjalankan Pemerintahan;

Untuk meniadakan kemampuan menjalankan pemerintahan dapat terjadi dengan beberapa cara dan tidak dipersoalkan jenis sarana dan cara yang dipergunakan dalam melakukan makar untuk mencapai tujuannya. Melakukan percobaan untuk menjadikan tidak mampu, dengan cara atau sarana yang tepat,

42 P. A. F Lamintang dan Theo Lamintang, Delik-delik. Khusus..., 33 perbuatannya secara berdiri sendiri dapat merupakan perbuatan yang dapat dihukum. Pengertian tidak mampu untuk menjalankan pemerintahan tidak dijumpai dalam undang-undang, hanya menurut Moch. Anwar dan beberapa penulis berikan contoh-contoh mengenai sarana yang diperlukan seperti kekerasan dan pemberian bahan-bahan berbahaya serta hal-hal yang dapat menimbulkan ketidakmampuan dalam tubuh dan fikiran maupun dalam kesusilaan. $^{43}$

Dalam hal ini harus dipahami ketidakmampuan dimaksudkan baik secara fisik maupun secara psikis. Selain itu untuk dapat didakwa melanggar Pasal 104 KUHP, seorang pelaku itu harus mempunyai pengetahuan bahwa makar yang ia lakukan itu ditujukan kepada seorang Presiden atau Wakil Presiden.

6. Presiden atau Wakil Presiden.

Objek dari perbuatan makar adalah Presiden atau Wakil Presiden. Hal ini dapat dinyatakan sebagai suatu kejahatan terhadap keamanan Negara yang dipersamakan dengan keamanan pimpinan negaranya. Jika tidak diketahui bahwa korban adalah kepala Negara, maka kejahatan itu bukan merupakan kejahatan terhadap keamanan Negara.

Di sini maksud atau niat harus ditujukan pada menghilangkan jiwa atau merampas kemerdekaan kepala Negara, jika tidak, maka kejahatan itu merupakan kejahatan pembunuhan biasa, pembunuhan berencana atau perampasan kebebasan dengan pemberatan.

\section{KESIMPULAN}

Sampai saat ini belum ada peraturan perundang-undangan yang secara resmi menerjemahkan WvSNI, terjemahan -
${ }^{43}$ H.A.K Moch. Anwar, Hukum Pidana Bagian Kemerdekaan Menyampaikan Pendapat... 
terjemahan yang ada seperti dari Moeljatno, Soesilo dan Badan Pembinaan Hukum Nasional merupakan bukan terjemahan resmi yang disahkan oleh Pemerintah, dengan kata lain KUHP saat ini merupakan KUHP dalam dua versi bahasa yakni Bahasa Indonesia dan Bahasa awalnya yaitu Bahasa Belanda, dengan demikian menelisik dari sejarah pengaturan makar dalam KUHP menunjukkan bahwasanya Makar adalah identik bahkan merupakan terjemahan langsung dari kata aanslag dengan demikian hendaknya makar harus memiliki pemaknaan yang sama dengan aanslag. Dan penyidik dalam menetapkan status tersangka kepada seorang dengan tuduhan makar harus merujuk dan menilai makar tersebut sebagai suatu serangan yang secara materil ditujukan sebagaimana dengan objek dari makar tersebut.

Terhadap kemerdekaan menyampaikan pendapat dikaitkan dengan pasal -pasal makar dalam KUHP, makar dikaitkan dengan dengan keberadaan Pasal 28E ayat (3) UUD 1945, dimana Ketentuan dalam Buku Kedua Bab I Tentang Kejahatan Terhadap Keamanan Negara Undang - Undang Nomor 1 Tahun 1946 Tentang Peraturan Hukum Pidana mencerminkan ketidakadilan (injustice) ketidakpastian hukum (legal uncertainty) terhadap para orang - orang yang menunjukkan ekspresinya dalam demokrasi untuk mengkritisi pemerintah atau Presiden dan Wakil Presiden, karena dengan adanya ketentuan ini tindakan yang dilakukan dalam rangka mempertahankan dan memperjuangkan hak-haknya serta membela hak-hak masyarakat untuk menyuarakan kritiknya terhadap kinerja pemerintah dapat dikualifikasikan secara sewenang-wenang menjadi suatu perbuatan yang dapat ditafsirkan dan dikualifikasi sebagai "maksud untuk menggulingkan pemerintahan". Padahal menuntut suatu hak baik individu maupun kolektif dijamin oleh berbagai perundang-undangan termasuk UUD 1945, sehingga mengakibatkan dilanggarnya jaminan kepastian hukum sebagaimana diatur dalam Pasal 28D ayat (1) UUD 1945 dan jaminan kepastian menyatakan pikiran dan pendapat yang diatur dalam Pasal 28E Ayat (2) dan (3) UUD 1945. Sehingga menetapkan status tersangka kepada subjek hukum yang melakukan aksi dan menyatakan pendapat dalam bentuk kritikan kepada Pemerintah, Presiden atau Wakil Presiden tidak dapat diproses secara pidana dengan pasal apapun termasuk dengan pasal makar dalam KUHP. 


\section{DAFTAR KEPUSTAKAAN}

Ali, Achmad, Menguak Teori Hukum Legal Theory dan Teori Peradilan Judicialprudence Termasuk. Integritasi Undang-Undang Legisprudence, Jakarta: Kencana, 2009.

Anshari, Delik Terhadap Keamanan Negara Makar di Indonesia Suatu Analisis Yuridis Normatif pada Studi Kasus Sultan Hamid II, Jakarta: Tesis Universitas Indonesia, 2012.

Anwar, H.A.K Moch., Hukum Pidana Bagian Khusus, Bandung: Alumni.

Asshiddiqie, Jimly, Gagasan Negara Hukum Indonesia.

Azhary, Muhammad Tahir, et al, Beberapa Aspek Hukum Tata Negara, Hukum Pidana, dan Hukum Islam, Jakarta: Kencana, 2012.

Chazawi, Adami, Kejabatan Terhadap Keamanan dan Keselamatan Negara, Jakarta: Raja Wali Pers, 2002.

Ed., KUHAP dan KUHP, Jakarta: Sinar Grafika, 2000.

Ed., Kitab Oendang-oendang Hoekoeman Bagi Hindia Belanda - Wetboek van Strafrecht voor Nederlandsch Indie, Batavia-C: Balai Poestaka, 1940.

El-Muhtaj, Majda, Hak Asasi Manusia Dalam Konstitusi Indonesia, Jakarta: Kencana Prenada Media Group, 2005.

Hamzah, Andi, Delik- delike Tertentu Speciale Delicten di Dalam KUHP, Jakarta: Sinar Grafika, 2015.

Hiariaje, Eddy O.S, Prinsip-Prinsip Hukum Pidana, Yogyakarta: Cahaya Atma Pustaka, 2016.

Janis, Mark W., An Introduction to International Law, New York: Aspen Publishers, 2003.

Konsideran Undang-Undang Nomor 27 Tahun 1999

Kusumaatmadja, Mochtar, Pengantar Hukum Internasional, Bandung: Bina Cipta, 1976.

Lamintang, P. A. F dan Theo Lamintang, Delik-Delik Khusus Kejahatan terhadap Kepentingan Hukum Negara, Jakarta: Sinar Grafika, 2010.

Loqman, Loebby, Delik Politik di Indonesia, Jakarta: Ind-Hill-Co, 1993.

MD, Moh. Mahfud, Perdebatan Hukum Tata Negara, Jakarta: Rajawali Pers, 2011.

Mertokusumo, Sudikno, Penemuan Hukum Sebuah Pengantar, Yogyakarta: Cahaya Atma Pustaka, 2009.

Nickel, James W., Hak Asasi Manusia, Refleksi Filosofis Atas Deklarasi Universal Hak Asasi Manusia, Terj. Titis Eddy Arini, Jakarta: Gramedia Pustaka Utama, 1996.

Prakoso, Djoko, Tindak Pidana Makar Manurut KUHP, Jakarta: Ghalia Indonesia, 1985.

Prodjodikoro, Wirjono, Tindak-tindak Pidana Tertentu di Indonesia, Bandung: Eresco, 1986.

Rahman, Abd. "Kebebasan Berpendapat: Tinjauan Filosofis Pasal 22 Deklarasi Kairo tentang HakAsasi Manusia dalam Islam." ALHURRIYAH: Jurnal Hukum Islam 3, no. 1 June 22, 2018): 81-94-94. doi:10.30983/alhurriyah.v3i1.531.

Reksodiputro, Mardjono, Pembaharuan Hukum Pidana Kumpulan Karangan, Vol. IV, Jakarta: Pusat Pelayanan Keadilan dan Pengabdian Hukum Universitas Indonesia, 2007.

Remmelink, Jan, Hukum Pidana: Komentar atas Pasal-Pasal Terpenting Dari KUHP Belanda dan Padanannya Dalam KUHP Indoenesia, 2003.

Saraswati, LG. dan Taufik Basari, dkk, Hak Asasi Manusia, Teori, Hukum, Kasus, Jakarta: UI Press, 2006.

Sidharta, B. Arief, "Kajian Kefilsafatan tentang Negara Hukum”, Jentera Jurnal Hukum Rule of Law Pusat Studi Hukum dan Kebijakan PSHK, vol. II no. 3, Jakarta: November, 2004, 124-125

Soesilo, R., Kitap Undang-Undang Hukum Pidana KUHP Serta Komentar komentarnya Lengkap Pasal demi Pasal, Bogor: Politea, 1996.

Suseno, Frans Magnis, Etika Politik Prinsip-prinsip Moral Dasar Kenegaraan Modern, Jakarta: Gramedia,1994.

Weissbrodt, David, Hak-Hak Asasi Manusia: Tinjauan Dari Perspektif Kesejarahan, Jakarta: Yayasan Obor Indonesia. 